\title{
Are antiretrovirals prescribed according to the recommended prescribed daily doses in the private healthcare sector in South Africa
}

\author{
Authors: \\ Norah L. Katende-Kyenda \\ Martie Lubbe ${ }^{2}$ \\ Juan H.P. Serfontein ${ }^{2}$ \\ Ilse Truter ${ }^{3}$

\begin{abstract}
Affiliations:
${ }^{1}$ Department of

University, South Africa
\end{abstract} \\ Pharmacology, Walter Sisulu
}

${ }^{2}$ Pharmacy Practice, North-

West University, South Africa

${ }^{3}$ Pharmacy Practice, Nelson

Mandela Metropolitan

University, South Africa

\section{Correspondence to:}

Norah Katende-Kyenda

Email:

nkyenda1@gmail.com

\section{Postal address:}

Private Bag X1, Mthatha,

Eastern Cape, South Africa

Dates:

Received: 08 June 2011

Accepted: 20 Sept. 2011

Published: 16 Nov. 2011

How to cite this article: Katende-Kyenda, N.L., Lubbe, M., Serfontein, J.H.P. \& Truter, I., 2011, 'Are antiretrovirals prescribed according to the recommended prescribed daily doses in the private health care sector in South Africa?', Health SA Gesondheid 16(1), Art. \#604, 9 pages. http://dx.doi org/10.4102/hsag.v16i1.604

(C) 2011. The Authors. Licensee: AOSIS OpenJournals. This work is licensed under the Creative Commons Attribution License.
Current antiretroviral treatment (ART) guidelines recommend different combinations that have led to major improvements in the management of HIV and AIDS in the developed and developing world. With the rapid approval of many agents, health care providers may not be able to familiarise themselves with them all. This lack of knowledge leads to increased risk of dose- prescribing errors, especially by non-HIV and AIDS specialists. The purpose of this retrospective non-experimental, quantitative drug utilisation study was to evaluate if antiretrovirals (ARVs) are prescribed according to the recommended prescribed daily doses (PDDs) in a section of the private health care sector in South Africa (SA). Analysed ARV prescriptions (49995, 81096 and 88988) for HIV and AIDS patients were claimed from a national medicine claims database for the period 1 January 2005 through to 31 December 2007. ARV prescriptions prescribed by general practitioners (GPs) with PDDs not according to the recommended ARV dosing increased dramatically, from $12.33 \%$ in 2005 to $24.26 \%$ in 2007. Those prescribed by specialists (SPs) increased from $15.46 \%$ in 2005 to $35.20 \%$ in 2006 and decreased to $33.16 \%$ in 2007. The highest percentage of ARV prescriptions with PDDs not according to recommended ARV dosing guidelines was identified in ARV regimens with lopinavir-ritonavir at a PDD of 1066.4/264 mg and efavirenz at a PDD of $600 \mathrm{mg}$ prescribed to patients in the age group of Group 3 (19 years $>$ age $\leq 45$ years). These regimens were mostly prescribed by GPs rather than SPs. There is a need for more education for all health care professionals and/or providers in the private health care sector in SA on recommended ARV doses, to avoid treatment failures, development of resistance, drug-related adverse effects and drug interactions.

Huidige riglyne vir behandeling met antiretrovirale middels beveel verskillende kombinasies aan wat tot groot verbetering in die beheer van MIV en VIGS in die ontwikkelde en ontwikkelende wêreld gelei het. Met die vinnige goedkeuring van talle nuwe middels kan dit gebeur dat verskaffers van gesondheidsorg nie kan bybly om hulle hiermee op hoogte te hou nie. Hierdie gebrek aan kennis lei tot ' $n$ hoër risiko vir foute in die voorgeskrewe dosis en veral deur persone wat nie spesialiste in MIV en VIGS is nie. Die doel van hierdie nie-eksperimentele, retrospektiewe, kwantitatiewe studie van die gebruik van geneesmiddels was om te bepaal of antiretrovirale middels in ' $\mathrm{n}$ deel van die privaat gesondheidsorgsektor in Suid-Afrika (SA) volgens die aanbevole voorgeskrewe daaglikse dosisse (VDD) voorgeskryf word. Voorskrifte van antiretrovirale middels (49995, 81096 en 88988) aan pasiënte met MIV en VIGS wat in die periode van 1 Januarie 2005 tot 31 Desember 2007 van 'n nasionale medisyne databasis geëis is, is ontleed. Voorskrifte van antiretrovirale middels deur algemene praktisyns (APs) met VDDs wat nie volgens die aanbevole dosisse vir antiretrovirale middels was nie, het dramaties van $12.33 \%$ in 2005 tot $24.26 \%$ in 2007 toegeneem. Die wat deur spesialiste (SPs) voorgeskryf is, het van $15.46 \%$ in 2005 tot $35.20 \%$ in 2006 toegeneem en in 2007 tot $33.16 \%$ gedaal. Die hoogste persentasie van voorskrifte vir antiretrovirale middels met VDDs wat nie volgens die riglyne was nie, was in die regimens met lopinavir-ritonavir met ' $\mathrm{n}$ VDD van 1066.4/264 mg en efavirens met ' $n$ VDD van 600 mg wat aan pasiënte in die ouderdomsgroep van ouer as 19 tot en met 45 jaar voorgeskryf is. Hierdie regimens is meer deur APs as deur SPs voorgeskryf. Daar is ' $n$ behoefte aan nog opleiding van alle gesondheidsprofessies en/of voersieners in die privaat gesondheidsorgsektor in SA oor die aanbevole antiretrovirale middel-dosisse om mislukking van behandeling, ontwikkeling van weerstand, nadelige effekte vanweë geneesmiddels en geneesmiddel interaksies te voorkom.

\section{Introduction}

\section{Background}

HIV and AIDS (human immunodeficiency virus and acquired immune deficiency syndrome) is a disease progression continuum, from testing HIV positive to having AIDS-defining illnesses such as pneumocystis carinii, opportunistic infections and 'signs of wasting syndrome' (Ward \& 
Kim 1999:50-51). The causative organism of AIDS is HIV that belongs to a group of retroviruses, a subgroup of lentoviruses that replicate slowly whilst they destroy the victim's CD4 lymphocytes, making the person susceptible to opportunistic infections (Ward \& Kim 1999:50-51). Antiretroviral (ARV) drugs have revolutionised HIV-infected patients' prognosis. ARVs do not cure HIV and AIDS but are used to suppress the replication of HIV to levels undetectable in the blood, and also help to increase the number of CD4 cells in the blood (Ward \& Kim 1999:68-69).

Although there have been numerous beneficial effects of antiretroviral therapy (ART), new problems have emerged which include poor patient adherence to their ARV regimens, drug interactions, drug-related adverse effects and virus resistance (Tourret et al. 2007:779). As a result of ART, HIV-infected patients live longer. ARV prescriptions have become increasingly complex, leading to a number of prescription errors. In one study the rate of prescription error increased from $2 \%$ to $12 \%$ in infected hospitalised patients as new classes of ARVs became available, the most common errors being overdosing and underdosing (Purdy et al. 2000:833). DeLorenze, Follansbee and Nguyen (2005:63) in their study on ARV drug prescription errors amongst outpatients confirmed the incidence of dosing errors to be 9.8 errors per 100 prescriptions. It was further confirmed that patients in the age group of older than 19 years to 45 years were at a higher risk of receiving an erroneous dose compared to patients in other age groups.

The World Health Organisation (WHO) estimated that of the 38.6 million people living with HIV and AIDS worldwide (Johansson 2007:1614), the 4.7 million living in sub-Saharan Africa urgently needed ART (United Nations programme for HIV and AIDS (UNAIDS)/WHO 2007). In 2007 South Africa (SA) had about 5 million people infected with HIV and AIDS which, according to the UNAIDS, was the highest number in any country (UNAIDS/WHO 2007). SA had prescribed minimum benefits for HIV and AIDS implemented in the private health care sector in 2005 (Erasmus 2007:777).

Despite the increased availability and affordability of ART, the proportion of HIV-positive people in SA eligible and receiving treatment is low (Johnson 2006). In mid-2005 an estimated 60000 people were receiving ART through medical schemes and community treatment programmes (Johnson 2006).

Current ART guidelines recommend different combinations, that have led to major improvements in the management of HIV and AIDS in the developed and developing world (Arshad et al. 2009). With the rapid approval of many new agents, health care providers may not be able to familiarise themselves with them all, and this leads to increased risk of dose-prescribing errors, especially by non-HIV and AIDS specialists (Purdy et al. 2000: 834). These errors can also occur at levels of dispensing by pharmacists and nurses and/or self-administration by patients themselves due to inadequate accessibility of prescriber's information, complicated regimens, and incorrect reporting by the patient (Heelon et al. 2007:2064). Medication-prescribing errors associated with highly active antiretroviral therapy (HAART) may lead to treatment failure and are multifactorial. Therefore health care professionals and providers caring for HIV-infected patients should be aware of dose-prescribing errors and employ strategies to prevent them.

Guidelines for the use of ARVs in adults and adolescents infected with HIV-1 were formulated by both the South African HIV Clinicians Society (SAHIVCS 2009) and the National Department of Health $(\mathrm{NDoH})$ and Human Services expert panel (DHHS 2008). ART refers to the ARV doses, frequencies and food restrictions prescribed for individual patients. In this study we only looked at the ARV doses. In SA both public and private sector patients commence ART if their CD4 counts are below 350 cells $/ \mathrm{mm}^{3}$ or at WHO stage 4 or if they have AIDS-defining illnesses such as wasting syndrome, recurrent severe bacterial infections, encephalopathy or tumours (Anabwani \& Jimbo 2005:5).

The private health care environment recommends the Aid for Aids (AfA) ART guidelines (AfA 2009), which are similar to those of the SAHIVCS, as shown in Table 1.

\section{Problem statement}

\section{Aims and objectives of the study}

Despite increased availability and affordability of ART in SA patients might not achieve maximum therapeutic goals. Incorrect prescribed daily doses (PDDs) of ARVs could result in ART-resistant strains of HIV, leading to poorer therapeutic outcomes at vastly more expense and with more side-effects than those from the initial ART guidelines (Heelon et al. 2007:2064). According to the WHO, PDDs are defined as the average doses prescribed according to a representative sample of prescriptions (WHO 2003). Therefore correct PDDs are beneficial to the individual patients, their communities and the country at large.

In this study PDDs were evaluated to see if they were adhering to recommended AfA ARV dosing. It is important that the PDD be related to the diagnosis made for the prescribed medication. In this study the reference guides used to evaluate PDDs were according to the recommended ARV-dosing guidelines. The research problem was thus to evaluate whether ARV prescriptions were prescribed according to the recommended AfA ARV dosing guidelines.

The purpose of the study was to evaluate whether ARV prescriptions by general practitioners (GPs) and specialists (SPs) were according to the recommended AfA ARV dosing, and to identify which regimens presented the most incorrect PDDs and in which age group of patients. The research question was: Are antiretroviral drugs prescribed according to the recommended ARV-dosing AfA guidelines? 
The above recommended ARV combinations and their PDDs according to AfA guidelines were for 2009 when the study was done. There are new AfA guidelines for 2010 and 2011.

To start ART the patient must be ready for treatment and have a WHO stage four or two CD4 blood counts lower than 350 cells $/ \mathrm{mm}^{3}$ done at least six weeks apart (AfA 2009). Certain disease management programmes in the private sector in SA use the initiation criteria for ART in children as shown in Table 2. In this study CD4 cell and viral load counts were not analysed, due to their unavailability from the PBM company database.

The recommended ART regimens in children are as follows:

For infants: Either 2 nucleoside reverse transcriptase inhibitors (NRTIs) +1 protease inhibitor (PI) (lopinavirritonavir) or 2 NRTIs +1 non-nucleoside reverse transcriptase inhibitor (NNRTI) (nevirapine) (not to be used if mother or infant received single-dose nevirapine as part of the strategy to prevent mother-to-child transmission).

For children: Either 2 NRTIs + PI (lopinavir-ritonavir) or NRTI + NNRTI (efavirenz or nevirapine) as recommended by the NDoH (2005).

\section{Significance of the study}

Advances and efforts made in treating HIV infection over the past years led to a decline in the morbidity and mortality associated with HIV and AIDS (Palella et al. 1998:853). ARVs have transformed HIV and AIDS from a life-threatening condition to a chronic disorder that can be effectively managed, resulting in delayed disease progression, improved survival and decreased hospitalisation for the HIV-infected patient (Wong 2008:117). Providing ART to HIV patients in SA might, however, have a limited impact on the development of the HIV and AIDS epidemic unless ARVs are prescribed and administered according to the recommended ARV dosing guidelines.

The influence of the prescriber on the prevalence of ARV prescriptions with incorrect PDDs has not been studied in the private sector in SA. The study evaluated whether GPs' and SPs' ARV prescriptions were according to the recommended AfA ARV dosing. Addressing this challenge could help achieve patients' adherence to ARV regimens and impact on virus resistance, drug interactions and drug-related adverse effects.

\section{Research methods and design Design}

A retrospective quantitative drug utilisation study was performed on data obtained from a South African PBM company which manages the medicine benefits of medical schemes in a section of the private health care sector. Data were selected for three years, from 1 January 2005 to 31 December 2007.

\section{Population and sample}

The total database consisted of 8506355 (2005), 9029912 (2006) and 8015538 (2007) prescriptions prescribed to 1218358 (2005), 1259099 (2006) and 911212 (2007) patients. This study was performed on 49995 (2005), 81096 (2006 and 88988 (2007) ARV prescriptions for 7664 (2005), 10162 (2006) and 10061 (2007) HIV and AIDS patients. There were five age groups assessed in this study: 0 years $\leq$ Group 1 $\leq 12$ years; 12 years $>$ Group $2 \leq 19$ years; 19 years $>$ Group $3 \leq 45$ years; 45 years > Group $4 \leq 59$ years; and Group $5>59$ years. Prescribers of ARV prescriptions were divided into GPs and SPs.

\section{Data collection methods}

Data were obtained directly from the central database of a South African PBM company; therefore there was no direct manipulation of the data during the data analysis process, It was assumed that all data obtained were correct and accurate.

\section{Data analysis}

Data were analysed using the Statistical Analysis System ${ }^{\circledR}$ SAS for Windows $9.1^{\circledR}$ (SAS Institute 2006-2007). Basic

TABLE 1: Recommended antiretrovirals combinations and their prescribed daily doses (AfA 2009).

\begin{tabular}{|c|c|c|c|c|}
\hline \multirow[t]{2}{*}{ PIs } & \multicolumn{2}{|c|}{ Dose for PI-naïve $\dagger$} & \multicolumn{2}{|c|}{ Dose for PI-experienced $\dagger$} \\
\hline & Nevirapine & Efavirenz & Nevirapine & Efavirenz \\
\hline Atazanavir-ritonavir & Not recommended & $400 / 100 \mathrm{mg}$ once a day & Not recommended & $400 / 100 \mathrm{mg}$ \\
\hline Darunavir-ritonavir & $800 / 100 \mathrm{mg}$ once a day & $800 / 100 \mathrm{mg}$ once a day & $600 / 100 \mathrm{mg}$ twice a day & $600 / 100 \mathrm{mg}$ twice a day \\
\hline lopinavir-ritonavir & $800 / 200 \mathrm{mg}$ once a day & $800 / 200 \mathrm{mg}$ once a day & $600 / 150 \mathrm{mg}$ twice daily & $600 / 150 \mathrm{mg}$ twice daily \\
\hline Saquinavir-ritonavir & $500 / 100 \mathrm{mg}$ twice a day & $500 / 100$ mg twice a day & $1600 / 100 \mathrm{mg}$ once a day & $1600 / 100 \mathrm{mg}$ once a day \\
\hline
\end{tabular}

Source: (AfA, 2009)

$\dagger$, 'Protease inhibitor (PI)-naïve' is a term used to describe HIV-infected individuals who have never taken or who have not previously been exposed to anti-HIV drugs. 'PI-experienced' is a term used to describe HIV-infected individuals who are currently being treated with anti-HIV drugs or who have taken anti-HIV drugs in the past.

TABLE 2: CD4 criteria for initiation of antiretroviral treatment in children in the private sector (AfA 2009).

\begin{tabular}{|c|c|c|c|c|}
\hline \multirow{2}{*}{ Criteria } & \multicolumn{4}{|c|}{ Age group } \\
\hline & $<12$ months & 12 - 35 months & 36 - 59 months & 5 years and over \\
\hline CD4 (\%) & All & $<20$ & $<20$ & $<15$ \\
\hline Absolute CD4 count (cells $/ \mathrm{mm}^{3}$ ) & - & $<750$ & $<500$ & $<350$ \\
\hline
\end{tabular}

Source: (AfA 2009) 
descriptive statistics, i.e. frequencies, the arithmetic mean (average) and standard deviations were used to characterise the study sample and calculations.

\section{Classification system used for ARVs}

ARV drug names were classified according to the pharmacological groups as described in the Monthly Index of Medical Specialities (MIMS) (Snyman 2009:359) as well as in the Regulations to the Medicine and Related Substances Act (Act 101 of 1965). The study evaluated potential PDDs in ARV prescriptions that were not according to recommended ARV dosing, in relation to the total number of patients and the five age groups mentioned above.

\section{Results}

\section{ARV prescriptions}

ARV prescriptions represented $0.59 \%(n=49995)$ of all prescriptions claimed during $2005(N=8506$ 355), 0.90\% $(n=81096)$ of $(N=9029$ 912) claimed during 2006 and $1.11 \%(n=88988)$ of $(N=8015535)$ claimed for 2007. It was observed that in the three years studied, GPs prescribed more ARV prescriptions than SPs, and these increased from 2005 to 2007 (Table 3). The highest percentage of ARV prescriptions for both GPs and SPs was observed for those with three ARV items, followed by those with two ARV items. Drug item (medicine item) is defined according to the Medicines and Related Substances Control Act of 1965, Act 101 of 1965 as amended (1965) as a 'substance intended for use in the diagnosis, cure, mitigation, treatment, modification or prevention of disease, abnormal physical or mental state or the symptoms thereof in man'. In this research the words 'drug items' are used interchangeably with the words 'medicine items'. In the South African context a prescription can consist of one or more medicine items (or drugs). No practical significant differences were found between the average numbers of ARV medicine items per prescription $(d<0.8)$ claimed per year for the different years.

\section{ARV prescriptions with incorrect PDDs}

Prescriptions by SPs and GPs with PDDs not according to the recommended ARV dosing according to patients' age for the three years of the study are shown in Tables 4 and 5. Of the total number of ARV prescriptions $(n=778)$ claimed during 2005, $12.72 \%(n=99)$ had PDDs not according to the recommended ARV dosing (DHHS 2008; AfA 2009) for different age groups. In 2006 the total number of ARV prescriptions $(n=1155)$ with PDDs not according to the recommended ARV dosing
(DHHS 2008; AfA 2009) increased dramatically to $21.47 \%$ $(n=248)$. The same trend was experienced during 2007 $(25.74 \% ; n=1177)$.

For 2005 a higher percentage (15.46\%) of ARV prescriptions prescribed by SPs $(15.46 \% ; n=97)$ had incorrect PDDs compared to those prescribed by GPs $(12.33 \%, n=681)$. For year 2006, of the total number of ARV prescriptions $(n=976)$ prescribed by GPs, $18.75 \%$ or 183 had incorrect PDDs. A much higher percentage $(35.20 \%, n=63)$ of ARV prescriptions prescribed by SPs $(n=179)$ had PDDs not according to the recommended ARV dosing. For 2007, of the total number of ARV prescriptions by GPs $(n=981)$, those with incorrect PDDs accounted for $24.26 \%(n=238)$, compared to a higher prevalence of $33.16 \%(n=65)$ of ARV prescriptions with PDDs prescribed by SPs $(n=196)$.

\section{ARV combinations with incorrect PDDs}

It should also be noted in Tables 4 and 5 that for the three years the highest numbers of incorrect PDDs were identified in ARV combinations of lopinavir-ritonavir at PDD 1066.4/264 $\mathrm{mg}$, with efavirenz at PDD $600 \mathrm{mg}$ and nevirapine at PDD 400 $\mathrm{mg}$. This was followed by indinavir $1600 \mathrm{mg}$ with ritonavir $800 \mathrm{mg}$; ritonavir $600 \mathrm{mg}$ with efavirenz $600 \mathrm{mg}$; saquinavir $800 \mathrm{mg}$ with efavirenz $800 \mathrm{mg}$ for both GPs and SPs, with the highest number of prescriptions prescribed by GPs to patients in the age group of Group 3, followed by patients in age group of Group 4. The highest number of ARV prescriptions with PDDs not according to recommended ARV dosing were for patients in the age group older than 19 years up to and including 45 years.

\section{Ethical considerations}

No specific patient, medical practice, pharmacy or medical scheme could be identified; thus confidentiality of information was maintained throughout the study. Permission to conduct the study was granted by the PBM company and approval was obtained from the Research and Ethics Committees of North-West University, Potchefstroom campus (ethical number 07M01) and Walter Sisulu University Mthatha campus.

\section{Reliability and validity}

The data for the study were obtained directly from the database and there was thus no direct manipulation of the data by the researcher. Data were obtained for a three-year

TABLE 3: Comparison of number of antiretrovirals prescriptions with potential drug-drug interactions, antiretroviral prescriptions with drug-drug interactionsand inappropriate prescribed daily doses.

\begin{tabular}{|c|c|c|c|c|c|c|c|c|}
\hline \multirow[t]{3}{*}{ Year } & \multicolumn{4}{|c|}{ ARV prescriptions with potential DDIs (level 2) } & \multicolumn{4}{|c|}{ ARV prescriptions with DDIs and PDDs not according to recommended ARV dosing } \\
\hline & \multicolumn{2}{|c|}{ GPs } & \multicolumn{2}{|c|}{ SPs } & \multicolumn{2}{|c|}{ GPs } & \multicolumn{2}{|c|}{ SPs } \\
\hline & $n$ & $\%$ & $n$ & $\%$ & $n$ & $\%$ & $n$ & $\%$ \\
\hline 2005 & 681 & 25.8 & 97 & 20.6 & 84 & 16.6 & 15 & 10.5 \\
\hline 2006 & 976 & 37.0 & 179 & 37.9 & 183 & 36.3 & 63 & 44.0 \\
\hline 2007 & 981 & 37.2 & 196 & 41.5 & 238 & 47.1 & 65 & 45.5 \\
\hline Total & 2638 & - & 472 & - & 505 & - & 143 & - \\
\hline
\end{tabular}

Source: Author's original data

$n$, given as means of number; DDI, drug-drug interaction; GPs, general practitioners; SPs, specialists. 
TABLE 4a: Number of antiretroviral prescriptions prescribed by specialists not according to the recommended antiretroviral dosing and age group.

\begin{tabular}{lccc}
\hline Age group (years) & \multicolumn{3}{c}{ Number of prescriptions } \\
\cline { 2 - 4 } Group 3 & $\mathbf{2 0 0 5}(\boldsymbol{n}=\mathbf{9 7})$ & $\mathbf{2 0 0 6}(\boldsymbol{n}=\mathbf{1 7 9})$ & $\mathbf{2 0 0 7}(\boldsymbol{n}=\mathbf{1 9 6})$ \\
& 6 & 25 & 23 \\
& 2 & - & - \\
& 1 & - & - \\
& 2 & 16 & 16 \\
& 2 & - & - \\
& 1 & - & - \\
Group 4 & 1 & - & - \\
& - & 22 & 22 \\
Group 5 & - & - & 3 \\
\hline Total & - & - & 1 \\
\hline
\end{tabular}

Source: Author's original data

$n$, given as means of number; Group 3, (19 years > age $\leq 45$ years); Group 4, (45 years > age $\leq 59$ years ); Group 5, (59 years > age).

period thus limiting external validity, implying that the results can only be generalised to the specific database used as well as to the specific study population from 2005 to 2007.

\section{Discussion \\ Outline of the results}

The aim of the study was to evaluate ARV prescriptions and their PDDs with specific reference to prescriber and age group in a section of the private health care sector in SA.

From the results it is evident that the percentage of ARV prescriptions that were claimed increased from year 2005 to 2007. This is supported by a WHO/UNAIDS press release in 2006 that the number of HIV-infected receiving treatment in sub-Saharan Africa was steadily increasing (WHO/UNAIDS 2005). It was also observed that most of the ARV prescriptions by GPs and SPs had two and three ARV items, supported by the fact that combination ARV regimens (especially those containing HIV type-1 PIs) provide clinical benefits achieving long-term virus suppression. Furthermore, the clinical value of triple-combination ART has been established by a number of large randomised controlled trials, showing striking improvements in disease markers (e.g. viral load, CD4 cell count) and improved survival and diminished disease progression relative to single- and double-agent therapy
(Erasmus 2007:777). According to AfA clinical guidelines, monotherapy is not recommended; it should only be used for prophylaxis (AfA 2009).

It was also noted that patients in age group (Group 3) in all three years presented the highest number of ARV prescriptions followed by patients (Group 4). A study performed in rural SA, in KwaZulu-Natal, the province with highest HIV and AIDS prevalence confirmed that the prevalence of HIV in adults (15-54 years) had reached 23\% in 2003/2004, with $27 \%$ of resident women (15-49 years) and $14 \%$ of resident men (15-54 years) (Welz et al., 2007:1467).

It is noted that ARV regimens most identified with PDDs not according to the recommended ARV dosing were between lopinavir-ritonavir (PI) and efavirenz (NNRTI), lopinavirritonavir with nevirapine (NNRTI), ritonavir (PI) with efavirenz, indinavir (PI) with ritonavir, saquinavir (PI) with efavirenz and saquinavir with ritonavir.

Because the pharmacokinetic profiles, side-effects and therapeutic outcomes of patients were not reported, this is a major limitation of the PBM database. It could be assumed that prescribers were not aware that the two regimens: PIs and NNRTIs presenting drug-drug interactions are the major causes of adverse drug reactions, so this caused prescribers to adjust the PDDs that were inappropriate. Studies performed by Seden, Back and Khoo (2009:5), Miller et al. (2007:1379) and Malaty and Kuper (1999:147) stated that all PIs and NNRTIs are predicted to have numerous drug-drug interactions because these are metabolised by the cytochrome P450 system and are also inhibitors of CYP3A4.

As observed in Tables 4a, 4b and 5a, 5b, the most commonly prescribed ARV drug was co-formulated lopinavir-ritonavir, the first and only co-formulated HIV-1 PI. It was reported in a review that large clinical trials have demonstrated lopinavir-ritonavir clinical efficacy in both ARV-naïve and -experienced patients (De Maat et al., 2003:223). The immunological and virological benefits of treatment with this agent have been proved in HIV-infected adults, adolescents and children (NDoH 2005).

TABLE 4b: Prescribed daily doses not according to the recommended antiretroviral dosing and age group as prescribed by specialists.

\begin{tabular}{|c|c|c|c|c|}
\hline \multirow[t]{3}{*}{ Age group (years) } & \multicolumn{4}{|c|}{ Specialists } \\
\hline & \multicolumn{2}{|c|}{ ARV combinations with average PDD } & \multicolumn{2}{|c|}{ ARV combinations with average PDD } \\
\hline & Medicine item & PDD & Medicine item & PDD \\
\hline \multirow[t]{7}{*}{ Group 3} & Lopinavir-ritonavir & $1066.4 / 264 \mathrm{mg}$ & Efavirenz & $600 \mathrm{mg}$ \\
\hline & - & $1142.6 / 282 \mathrm{mg}$ & - & $600 \mathrm{mg}$ \\
\hline & - & $3999 / 990 \mathrm{mg}$ & - & $1200 \mathrm{mg}$ \\
\hline & Lopinavir-ritonavir & $1066.4 / 264 \mathrm{mg}$ & Nevirapine & $400 \mathrm{mg}$ \\
\hline & - & 799.8/198 mg & - & $500 \mathrm{mg}$ \\
\hline & Indinavir & $800 \mathrm{mg}$ & Ritonavir & $1200 \mathrm{mg}$ \\
\hline & Indinavir & $1600 \mathrm{mg}$ & Efavirenz & $1200 \mathrm{mg}$ \\
\hline \multirow[t]{2}{*}{ Group 4} & Lopinavir-ritonavir & $1066.4 / 264 \mathrm{mg}$ & Efavirenz & $600 \mathrm{mg}$ \\
\hline & Lopinavir-ritonavir & $1066.4 / 264 \mathrm{mg}$ & Nevirapine & $400 \mathrm{mg}$ \\
\hline Group 5 & Lopinavir-ritonavir & $3999.9 / 990 \mathrm{mg}$ & Efavirenz & $600 \mathrm{mg}$ \\
\hline
\end{tabular}

Source: Author's original data

ARV, antiretroviral; PDD, prescribed daily doses; Group 3, (19 years > age $\leq 45$ years); Group 4, (45 years > age $\leq 59$ years ); Group 5, (age > 59 years). 
TABLE 5a: Number of antiretroviral prescriptions prescribed by general practitioners not according to the recommended antiretroviral dosing and age group.

\begin{tabular}{|c|c|c|c|}
\hline \multirow[t]{2}{*}{ Age group (years) } & \multicolumn{3}{|c|}{ Number of prescriptions by years } \\
\hline & $2005(n=681)$ & $2006(n=976)$ & $2007(n=981)$ \\
\hline \multirow[t]{3}{*}{ Group 1} & 8 & 6 & 6 \\
\hline & - & - & 9 \\
\hline & 4 & 3 & - \\
\hline \multirow[t]{16}{*}{ Group 3} & 30 & 101 & 145 \\
\hline & - & 26 & - \\
\hline & 1 & - & - \\
\hline & - & - & 3 \\
\hline & 15 & - & 8 \\
\hline & 1 & - & - \\
\hline & - & 1 & - \\
\hline & - & 2 & - \\
\hline & - & - & 9 \\
\hline & 1 & - & - \\
\hline & - & 3 & - \\
\hline & 1 & - & - \\
\hline & 2 & - & - \\
\hline & - & 14 & 2 \\
\hline & 1 & - & - \\
\hline & - & - & 18 \\
\hline \multirow[t]{4}{*}{ Group 4} & 16 & 11 & 17 \\
\hline & - & 7 & - \\
\hline & 1 & - & - \\
\hline & - & - & 13 \\
\hline \multirow[t]{4}{*}{ Group 5} & 3 & - & - \\
\hline & - & - & 8 \\
\hline & - & 9 & - \\
\hline & - & 2 & - \\
\hline Total & 84 & 185 & 238 \\
\hline
\end{tabular}

Source: Author's original data

$n$, given as means of number; Group 1, ( 0 years $>$ age $\leq 12$ years) Group 3, (19 years $>$ age $\leq 45$ years); Group 4 , ( 45 years > age $\leq 59$ years ); Group 5 , (59 years $>$ age).
Results obtained for the three years of study for both GPs and SPs prescribing ARV regimens with incorrect PDDs are shown in Tables 4 and 5. As observed for the three years, GPs prescribed lopinavir-ritonavir for patients in the age group of Group 1. One of the limitations of this study was that the weights of children were not available; therefore it was not clear to which patients' weight and specific age this co-formulation was prescribed. Otherwise the safety, efficacy and pharmacokinetic profiles of lopinavir-ritonavir in paediatric patients below the age of 6 months have not been established. It was assumed that patients were older than 6 months who received 20 prescriptions for lopinavir-ritonavir $800 / 200 \mathrm{mg}$ and efavirenz $200 \mathrm{mg}$; lopinavir-ritonavir $320 / 80 \mathrm{mg}$ and nevirapine $2600 \mathrm{mg}(n=7)$ and lopinavirritonavir 640/160 mg; with efavirenz $350 \mathrm{mg}(n=9)$.

According to the SA treatment guidelines for the management of HIV-infected children $(\mathrm{NDoH} 2005)$ the recommended paediatric dose for lopinavir-ritonavir is $<15 \mathrm{~kg}+12 \mathrm{mg}$ lopinavir $/ \mathrm{kg}$ and $\geq 15 \mathrm{~kg}=10 \mathrm{mg}$ lopinavir $/ \mathrm{kg}$ twice daily. In this case lopinavir-ritonavir was prescribed in a higher PDD considering one capsule of lopinavir-ritonavir to be $133.3 / 33.3 \mathrm{mg}$, and the maximum dose should be three capsules (399.9/99.9 mg) (NDoH 2005). If given in higher PDDs the patient can experience side-effects like diarrhoea, nausea, vomiting, hyperlipidaemia and glucose intolerance. Neither details of change in doses of ARVs nor side-effects experienced by patients were provided in the database; this was a limitation of this study as key confounding variables were not available.

TABLE 5b: Prescribed daily doses not according to the recommended antiretroviral dosing and age group as prescribed by general practitioners.

\begin{tabular}{|c|c|c|c|c|}
\hline \multirow[t]{3}{*}{ Age group (years) } & \multicolumn{4}{|c|}{ General practitioners } \\
\hline & \multicolumn{2}{|c|}{ ARV combinations with average PDD } & \multicolumn{2}{|c|}{ ARV combinations with average PDD } \\
\hline & Medicine item & PDD & Medicine item & PDD \\
\hline \multirow[t]{3}{*}{ Group 1} & Lopinavir-ritonavir & $800 / 200 \mathrm{mg}$ & Efavirenz & $200 \mathrm{mg}$ \\
\hline & - & $640 / 160 \mathrm{mg}$ & Efavirenz & $350 \mathrm{mg}$ \\
\hline & - & $320 / 80 \mathrm{mg}$ & Nevirapine & $2600 \mathrm{mg}$ \\
\hline \multirow[t]{16}{*}{ Group 3} & Lopinavir -ritonavir & $1066.4 / 264 \mathrm{mg}$ & Efavirenz & $600 \mathrm{mg}$ \\
\hline & - & $1066.4 / 264 \mathrm{mg}$ & - & $400 \mathrm{mg}$ \\
\hline & - & $4500 / 3999 \mathrm{mg}$ & - & $1800 \mathrm{mg}$ \\
\hline & - & $1599.6 / 264 \mathrm{mg}$ & - & $600 \mathrm{mg}$ \\
\hline & Lopinavir-ritonavir & $1066.4 / 264 \mathrm{mg}$ & Nevirapine & $400 \mathrm{mg}$ \\
\hline & - & $1066.4 / 264 \mathrm{mg}$ & - & $500 \mathrm{mg}$ \\
\hline & - & $1244 / 308 \mathrm{mg}$ & - & $400 \mathrm{mg}$ \\
\hline & - & 799.8/198 mg & - & $1600 \mathrm{mg}$ \\
\hline & - & 799.8/198 mg & - & $500 \mathrm{mg}$ \\
\hline & Ritonavir & $300 \mathrm{mg}$ & Efavirenz & $1800 \mathrm{mg}$ \\
\hline & - & $600 \mathrm{mg}$ & - & $600 \mathrm{mg}$ \\
\hline & Indinavir & $2400 \mathrm{mg}$ & Ritonavir & $3000 \mathrm{mg}$ \\
\hline & - & $800 \mathrm{mg}$ & - & $800 \mathrm{mg}$ \\
\hline & - & $1600 \mathrm{mg}$ & - & $800 \mathrm{mg}$ \\
\hline & Indinavir & $2400 \mathrm{mg}$ & Efavirenz & $1800 \mathrm{mg}$ \\
\hline & Saquinavir & $800 \mathrm{mg}$ & Efavirenz & $800 \mathrm{mg}$ \\
\hline \multirow[t]{4}{*}{ Group 4} & Lopinavir-ritonavir & $1066.4 / 264 \mathrm{mg}$ & Efavirenz & $600 \mathrm{mg}$ \\
\hline & & $1066.4 / 264 \mathrm{mg}$ & Efavirenz & $400 \mathrm{mg}$ \\
\hline & Lopinavir-ritonavir & $1066.4 / 264 \mathrm{mg}$ & Nevirapine & $500 \mathrm{mg}$ \\
\hline & Saquinavir & $800 \mathrm{mg}$ & Ritonavir & $800 \mathrm{mg}$ \\
\hline \multirow[t]{4}{*}{ Group 5} & Lopinavir-ritonavir & $1066.4 / 264 \mathrm{mg}$ & Nevirapine & $400 \mathrm{mg}$ \\
\hline & - & - & - & $500 \mathrm{mg}$ \\
\hline & Lopinavir-ritonavir & $1066.4 / 264 \mathrm{mg}$ & Efavirenz & $400 \mathrm{mg}$ \\
\hline & - & $1066.4 / 264 \mathrm{mg}$ & - & $500 \mathrm{mg}$ \\
\hline
\end{tabular}


In this study nevirapine was also prescribed at a higher dose of $2600 \mathrm{mg}$ to patients in Group 1 for the years 2005 and 2006. The recommended paediatric dose for nevirapine is $10 \mathrm{mg} /$ $\mathrm{ml}$ or $200 \mathrm{mg}$ tablet as an initial dose and $4 \mathrm{mg} / \mathrm{kg}$ once daily for 14 days followed by a maintenance dose of $7 \mathrm{mg} / \mathrm{kg}$ twice daily for children $<8$ years old, or $4 \mathrm{mg} / \mathrm{kg}$ twice daily for children $>8$ years old (NDoH 2005). At such a high dose the patient may experience adverse effects like rash including Stevens-Johnson syndrome, and symptomatic hepatitis including fatal hepatic necrosis.

Results from this study demonstrated that GPs prescribed lopinavir-ritonavir at higher PDDs of 1066.4/264 mg; $4500 / 3999 \mathrm{mg}$; and $1599.6 / 264 \mathrm{mg}$ to patients patients in Group 3 for the three years studied. The standard adult dose for lopinavir-ritonavir is $400 / 100 \mathrm{mg}$ (two tablets or $5 \mathrm{ml}$ ) twice daily or $800 / 200 \mathrm{mg}$ (four tablets or $10 \mathrm{ml}$ ) once daily. Another limitation of this study was that information about ARV-naïve or ARV-experienced patients was not available from the PBM database. Otherwise once-daily dosing for lopinavir-ritonavir is only recommended for treatmentnaïve patients, not for those receiving efavirenz, nevirapine or nelfinavir.

When lopinavir-ritonavir is given with efavirenz or nevirapine the recommended dose for treatment-experienced patients is $600 / 150 \mathrm{mg}$ (three oral tablets twice daily) or $533 / 133 \mathrm{mg}$ ) (6.7 $\mathrm{ml}$ oral solution) twice daily with food (Purdy et al. 2009 \& NDoH 2005).

It was also revealed that other ARV regimens with incorrect PDDs were ritonavir and indinavir, efavirenz, and saquinavir. Ritonavir, a PI, is used as a booster in ARV combination therapy. The concurrent administration of ritonavir markedly inhibits CYP3A4 with another PI like saquinavir substantially increasing plasma concentrations of saquinavir, thus reducing the adverse effects. This means there is less frequent and thus more convenient dosing, with fewer tablets and food restrictions which, in turn, may enhance patient adherence and higher plasma PI levels, with the potential to overcome viral resistance to the PI (Murphy et al. 2008:1).

It was observed in this study that ritonavir was given with other PIs in PDDs of $3000 \mathrm{mg}, 1200 \mathrm{mg}, 800 \mathrm{mg}$ and $600 \mathrm{mg}$. The recommended dosages of $100 \mathrm{mg}$ capsules or $600 \mathrm{mg} / 7.5$ $\mathrm{ml}$ solutions in adults are $600 \mathrm{mg}$ every 12 hours (when ritonavir is used as sole PI). As a pharmacokinetic booster for other PIs the recommended dosing is $100-400 \mathrm{mg}$ per day in 1-2 divided doses (DHHS 2008). Review of the literature showed that boosted PI regimens that utilise a low dose of ritonavir (100 - $200 \mathrm{mg}$ ) appear to offer the best balance of efficacy and tolerability.

Results from this study revealed that ritonavir $800 \mathrm{mg}$ was administered with saquinavir $800 \mathrm{mg}$. These PDDs are not acceptable according to the treatment guidelines (DHHS 2008), although it was reported that when administered with saquinavir, ritonavir enhances the bioavailability and prolongs the elimination half-life of saquinavir such that its plasma-concentration time increased as much as 30- to 50-fold compared to saquinavir alone (Hsu et al. 1997:898). Therefore the recommended combination dosage of ritonavir and saquinavir was reported to be $400 / 400 \mathrm{mg}$ since this appeared to have extremely potent ARV activity, judged on the basis of documented durable responses observed in patients (Cameron et al. 1999:214).

In this study indinavir was administered with ritonavir at PDDs of $2400 \mathrm{mg}$ and $3000 \mathrm{mg}$ respectively. These doses are considered to be high, considering that indinavir has a very short half-life because of the high systemic clearance; therefore the recommended dose is $800 \mathrm{mg}$ every 8 hours (AfA 2009). Indinavir is administered with ritonavir to improve its bioavailability and to prolong the elimination half-life, thus reducing the total dose necessary to achieve a potent ARV plasma concentration. The recommended dose for $200 \mathrm{mg}, 333 \mathrm{mg}$ and $400 \mathrm{mg}$ capsules of indinavir is $800 \mathrm{mg}$ every 8 hours if given alone, but with ritonavir the dosages should be $800 \mathrm{mg}$ for indinavir and $100 \mathrm{mg}$ or 200 $\mathrm{mg}$ for ritonavir every 12 hours (DHHS 2008).

\section{Practical implications}

Patients who receive highly active ART have a better survival rate than those that do not. However, ARVs have to be prescribed and administered in their correct doses for patients to achieve an optimal therapy. Results from this study highlight the importance of correct ARV dosing to avoid patients' problems of non-adherence, virus resistance, drug-related adverse effects and drug interactions.

\section{Contribution to current knowledge}

Drug interactions as well as incorrect PDDs of ARVs in terms of overdosing and potential drug interactions lead to adverse effects that could result in non-adherence to ARVs in HIV and AIDS patients. This further complicates the long-term management of the disease, which requires lifelong HAART. Yet sustained adherence is an essential tool of the long-term efficacy of ART (e.g. significant reductions in viral load, drug resistance, deterioration of health status and treatment failure) (Potcho et al. 2010:11).

\section{Clinical and statistical significance of the study}

With the introduction of HAART, ART has become increasingly complex, this leading to a certain number of prescription errors as new classes of ARVs become available. Incorrect dosing of ARV drugs, especially in patients with other chronic conditions like kidney disease who are undergoing haemodialysis, osteoporosis, heart disease, hypertension or abnormal hepatic function, leads to serious adverse events such as toxicity, viral resistance or treatment inefficacy (Tourret et al. 2007:779). This study emphasises the need for more education for health care professionals in $\mathrm{SA}$ on the recommended ARV doses to ensure effective use of ART. 


\section{Limitations of the study}

Some limitations of this study were the non-availability of patient clinical data to do in-depth clinical evaluation of PDDs. The data were obtained directly from the medicine claims database, which does not capture these data. Information on ARV-naïve or -experienced patients, CD4 values and viral loads were unavailable. Furthermore, data related to ARV doses initiated, changes made to the doses for reasons best known to prescribers, records of changed doses, success of the treatment, pharmacokinetic profiles, side-effects and therapeutic outcomes of the patients were not available in the database. The clinical relevance of the identified PDDs was evaluated according to criteria stated in the literature. However, the results emphasised the possibility of PDDs that could have led to severe problems.

A further limitation of the study was that no differentiation could be made between the prescription patterns of dispensing doctors versus pharmacy-dispensed prescriptions. This result emphasises the important role of prescribers and retail pharmacists in ensuring the appropriate use of ARVs.

\section{Recommendations}

Appropriate use of ARVs is essential to avoid virological failure, development of resistance to ARVs and increased mortality rates (Marazzi et al. 2006:34). Therefore the following are recommended:

- There is a need for collaboration amongst the prescribers and retail pharmacists, for pharmacists to be able to detect and correct prescriptions with incorrect doses by the prescribers at the level of dispensing. This is one of the primary responsibilities of specific pharmacists.

- The importance of educating health care providers in the appropriate use of ARVs specifically in the private health care sector is of SA is emphasised.

- There is a need for continuous monitoring and evaluation tools when handling medicines that are prone to cause more negative consequences when used inappropriately, especially in cases of infectious diseases that are societal problems such as HIV and AIDS.

- Future studies need to be performed on in-depth clinical evaluation of PDDs using clinical data of patients.

\section{Conclusion}

In this study inappropriate PDDs were identified between ARV agents prescribed in different regimens according to prescriber and age groups. There were more GP prescriptions for ARVs than SP prescriptions. It was observed that for the three years 2005-2007 a higher percentage of ARV prescriptions prescribed by SPs had PDDs not according to the recommended ARV doses. It is therefore recommended that more education be provided, for example by SAHIVCS Guidelines (2009), to health care providers in the private health care sector in SA on the recommended ARV doses so as to achieve optimal therapy.

\section{Acknowledgements}

We thank the managers of the PBM that provided the data for the research project and the South African Medical Research Council for financial assistance.

\section{Competing interest}

The authors declare that they have no financial or personal relationship which may have inappropriately influenced them in writing this paper.

\section{Authors' contributions}

N.L.K-K. was responsible for the entire writing up of the manuscript, which involved the initial planning and designing of it, statistical analysis, interpretation of results and final writeup. M.L. was involved in the original planning and design of study, statistical analysis and guidance in the interpretation of results and reviewed the manuscript. J.H.P.S. was involved in the original planning and design of study, and provided guidance in the interpretation of results and reviewed the manuscript. I.T. was involved in the original planning and design of the manuscript, guidance in the interpretation of results and final review of the manuscript.

\section{References}

Aid for Aids, 2009, 'Selecting Drug Combinations', AfA Clinical Guidelines. http:// aidforaids.co.za/ex_MEDSCHEME_VS07/Documents/AFA/Guidelines_book Final.pdf

Anabwani, G. \& Jimbo, W., 2005, Guidelines on antiretroviral treatment, rev., edn., Ministry of Health, Gaborone.

Arshad, S., Rothberg, M., Rastegar, D.A., Spooner, L,M. \& Daniel S.D., 2009, 'Survey of physician knowledge regarding antiretroviral medications in hospitalised HIVinfected patients', Journal of the International AIDS Society 12,1. http://dx.doi. org/10.1186/1758-2652-12-1

Cameron, D.W., Japour, A.J., Xu, Y., Hsu, A., Mellors, J., Farthing, C., et al., 1999 'Ritonavir and saquinavir combinations therapy for the treatment of HIV infection', AIDS 13, 213-224.

De Maat, M., De Boer, A., Koks, C., Mulder, J.W., Meenhorst, P.L., van Gorp, E.C., et al., 2004, 'Evaluation of clinical pharmacist interventions on drug interactions in outpatient pharmaceutical HIV-care', Journal of Clinical Pharmacy \& Therapeutics 29(2), 121-130.

DeLorenzo, G.N., Follansbee, S.F. \& Nguyen, D.P., 2005, 'Medication error in the care of HIV/AIDS patients: electronic surveillance, confirmation, and adverse events', Medical Care 43(9 suppl), 63-68.

Department of Health and Human Sciences, 2008, Guidelines for the use of antiretroviral agents in HIV-1-infected adults and adolescents, John Hopkins University, Baltimore, viewed 09 April 2009, from http://aidsinfo.nih.gov/ contentfiles/AdultsandadolescentGI.pdf

Erasmus, S., 2007, 'Medical Schemes in South Africa HIV becomes prescribed minimum benefit', viewed 17 July 2007, from http://www.health24.com/medical/ condition_centres/777-792-2002- 2007,30583.asp

Heelon, M., Skiest, D., Tereso, G., Meade, L., Weeks, J., Pekow, P., et al., 2007, 'Effect of a clinical pharmacist's interventions on duration of antiretroviral-related errors in hospitalized patients', American Journal of Health-Systems Pharmacy 64(19), 2064-2068.

Hsu, A., Granneman, G,R., Witt, G., Locke, C., Denissen, J., Molla, A., et al., 1997 Multiple-dose pharmacokinetics of ritonavir in human immunodeficiency virusinfected subjects', Antimicrobial Agents and Chemotherapy 41(5), 898-905.

Jani, A.A., Stewart, A., Nolen, R.D. \& Travel, I., 2002, 'Medication adherence and patient education in HIV/AIDS', viewed 06 May 2005, from http://faetc.org/PDF/ Primary Care Guide/0-Medication-Adherence-and Patient-Education.pdf

Johansson, L.M., 2007, 'Fiscal implications of AIDS in South Africa', European Economic Reviews 51, 1614-1640.

Johnson, L., 2006, 'Estimated numbers of patients on antiretroviral treatments in the South African private health sector', AIDS Analysis Africa Online Jan/Feb, 4-6.

Malaty, L.I. \& Kuper, J.J., 1999, 'Drug interactions of HIV protease inhibitors', Drug Safety 20(2), 147-169.

Miller, C.D., El-Kholi, R., Faragon, J.J., Lodise, T.P., 2007, 'Prevalence and risk factors for clinically significant drug interactions with ARV therapy', Pharmacotherapy 27(10), 1379-1386. 
Marazzi, M.C., Bartolo, M., Gialloretti, L.E., Germano, P., Guidotti, G. \& Liotta, G., et al., 2006. 'Improving adherence to highly active antiretroviral therapy in Africa: The DREAM programme in Mozambique'. Health Education Research 21(1), 34-42.

Murphy, R.L., Da Silva, B.A., Hicks, C.B., Eron, J.J., Gulick, R.M., Thompson, M.A. et al., 2008 , 'Seven- year efficacy of a lopinavir/ritonavir regimen in antiretroviral-naïve HIV-1-infected patients'. HIV Clinical Trials 15:9(1), 1-10.

National Department of Health, 2004, Guidelines for the management of HIV-infected in South Africa, Jacana Media, Pretoria. viewed 10 March 2009, from http://www. healthlink.org.za/uploads/files.sa_ART-Guidelines.pdf

National Department of Health South Africa, 2005, National Antiretroviral Treatment Guidelines. ARV choices for children. Guidelines for the management of HIVinfected children, Jacana Media, Pretoria.

Palella, F.J., Delaney, K.M., Moorman, A.C., Loveless, M.O., Fuhrer, J., Satten, G.A. et al., 1998, 'Declining morbidity and mortarity among patients with advanced
human immunodeficiency virus infection', New England Journal of Medicine 338 , 853-860.

Potcho, Y., Tchamdja, K., Balogou, A., Pitche, V., Guissou, I. P. \& Kassang, E.K., 2010, 'Knowledge and adherence to antiretroviral therapy among adult people living with HIV/AIDS treated in the health care centres of the association "Espoir Vie Togo," West Africa', BMC Clinical Pharmacology 10, 11, viewed 16 September 2009, from http://www.blomedcentral.com/1472-6904/10/11

Purdy, B.D., Raymond, A.M. \& Lesar, T.S., 2000, 'Antiretroviral prescribing errors in hospitalised patients', Annals of Pharmacotherapy 34, 833-838.

Seden, K., Back, D. \& Khoo, S., 2009, 'Antiretroviral drug interaction: often recognized, Frequently unavoidable, sometimes unmanageable', Journal of Antimicrobial Chemotherapy $64,5-8$.
Snyman, J.R., 2009, 'Antimicrobials: Anti-viral agents' in J.R. Snyman (ed.), Mims $s^{T M}$ Monthly Index of Medical Specialities 47(3),359-371, Jonnic Mims, Pinegowrie.

South African HIV Clinicians Society, 2009, 'South African HIV Clinicians Society Clinical Guidelines: Antiretroviral therapy in Adults', viewed 25 January 2009, from http:// www.hst.org.za/uploads/files/clincalguide_adults.pdf

Tourret, J., Tostivint, I., Du Montcel, S.T., Karie, S., Launay-Vacher, V., Vigneau, C., et al. 2007, 'Antiretroviral drug dosing errors in HIV-infected patients undergoing hemodialysis', Clinical Infectious Diseases 15(45), 779-784.

UNAIDS/World Health Organization, 2007, 'AIDS epidemic update', viewed 06 November 2009, from http://data.unaids.org/pub/EPISlides/2007-epiupdate-en.pdf

Ward, D.E \& Kim, M., 1999, The complete guide to understanding HIV and AIDS, The AmFAR AIDS Handbook, Norton, New York.

Welz, T., Hosegood, V., Jaffar, S., Batzing-Feigenbaum, J., Herbst, K. \& Newell, M,L, 2007, 'Continued very high prevalence of HIV infection in rural KwaZulu-Natal, South Africa: A population-based longitudinal study', AIDS 21(11), 1467-1472.

WHO/UNAIDS (World Health Organisation/United Nations Program on HIV/AIDS), 2006, 'Progress of global access to HIV antiretroviral therapy', viewed 07 October 2008, from http://www.who.int/hiv/pub/progressreports/3by5\%Progress $\% 20$ ReportElight.pdf

WHO (World Health Organisation), 2003, Introduction to drug utilization research, WHO, Oslo, Norway.

Wong, W.K.T. \& Ussher, J.M., 2008, 'Life with HIV and AIDS in the Era of effective treatments: 'It's not just about living longer', Social Theory \& Health 6, 117-131. 